\title{
PLASMA PROTEIN CHANGES AND SUSPENSION STABILITY OF THE BLOOD IN LOBAR PNEUMONIA
}

\author{
By JOHANNES K. MOEN AND HOBART A. REIMANN \\ (From the Department of Medicine, University Hospital, University of Minnesota Medical \\ School, Minneapolis)
}

(Received for publication November 12, 1932)

Numerous studies have been made on the relation of fractional blood protein changes to bacterial infection and immunity. The subject is of especial importance in view of the renewed interest regarding the association of immune bodies with the globulins and recent studies in regard to the effects of blood protein changes and plasma viscosity on specific and non-specific agglutination reactions $(1,2)$. Since the early experiments of Langstein and Mayer (3), it has been generally found that a relative or absolute increase of the globulin fraction and a decrease in the albumin fraction occur during and after various bacterial infections. Glaessner (4) and later Hurwitz and his co-workers (5) showed that increases in globulin may occur during the course of immunization as well. They believed that the globulin increase indicated disturbed metabolism and that no direct parallelism existed between the amount of globulin and the degree of immunity. There was no constant relationship between the increased amount of globulin and the antitoxic potency of prepared sera. Similar findings were noted by Schmidt and Tuljtschinskaja (6) and others. Studies on fractional blood protein changes in malaria, typhoid fever and after typhoid vaccination were made by Lloyd and Paul (7). They observed a marked decrease in the albumin fraction, an increase in the euglobulin and slight or no changes in the total globulin during the acute stage of typhoid fever and malaria. Similar but less marked changes followed vaccination with typhoid bacilli.

Many studies have been made on the blood protein changes in lobar pneumonia. Kumpf (8) collected data from 29 reports. It was generally agreed that the total protein was lowered, the fibrinogen and globulin increased and the albumin decreased in amount. No particular attention, however, was given to the speed with which changes in plasma proteins occur after the onset of infection or the time required before the normal equilibrium was regained.

Increase of plasma globulin and fibrinogen during infections causes a decrease of the suspension stability of the blood and consequent reduction of the sedimentation time of erythrocytes. The correlation between plasma protein changes and sedimentation time has been demonstrated 
repeatedly $(9,10,11,12,13)$. In a statistical analysis of the effect of blood protein fractions on the sedimentation rates in a large series of mixed clinical cases, Westergren and his co-workers (12) found a distinct correlation for fibrinogen and globulin and a negative correlation for albumin. Other factors, including hydremia, anemia, changes in cell volume and color index, also influence the suspension stability $(14,15,16$, 17). Possibly because of these other factors, a number of observers have been unable to establish a constant correlation between fractional protein changes and sedimentation time $(18,19,20,21)$. In two reports $(19,21)$ the changes in the amount of fibrinogen, which is known to play the most important role in suspension stability, were not measured.

The studies reported in this paper were undertaken to determine the correlation between fractional plasma protein changes, plasma viscosity and the sedimentation time of erythrocytes during and after lobar pneumonia.

\section{METHODS}

Plasma Protein Determinations (Supervised by Dr. Grace Medes). Twenty cc. of blood was withdrawn from the arm vein with minimum stasis, and oxalated. Plasma protein fractions were determined by Berglund's modification (22) of Howe's method using sodium sulphate as a salting-out agent. Nitrogen determinations were made by the microKjeldahl technic. The average normal protein values obtained with this method in grams per $100 \mathrm{cc}$. plasma were:

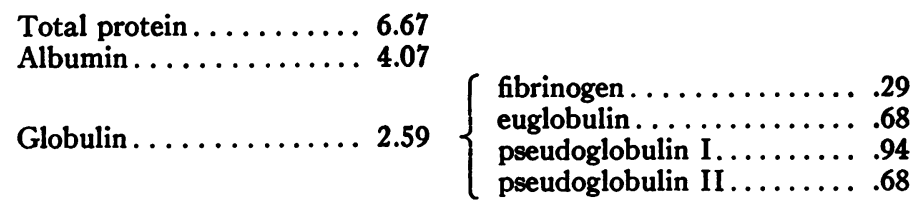

Sedimentation time. At the risk of confusing comparative data, the sedimentation time was observed by employing the usual standard hospital apparatus in place of special tubes. Nine-tenths cc. of blood was drawn into a tuberculin syringe $(4 \mathrm{~mm}$. diameter) containing $0.1 \mathrm{cc}$. of a 10 per cent solution of sodium citrate. The syringe was inverted a number of times to insure thorough mixing, the needle was removed and replaced by a short piece of rubber tubing. The end of the tube was bent back along the barrel of the syringe and fastened with a rubber band. The syringe was placed in a vertical position, stoppered and observed at room temperature. The number of minutes required for the erythrocyte level to reach the $0.6 \mathrm{cc}$. mark was arbitrarily considered to be the sedimentation time. The average normal sedimentation time by this method was 3 hours or more.

The Hess viscosimeter was used for the determination of plasma viscosity. According to the technic employed the viscosity of normal plasma was from 1.6 to 1.7 . 


\section{RESULTS}

The sedimentation time was repeatedly determined in 28 cases during the course of lobar pneumonia and in convalescence, some of the observations being made by one of us several years ago during the course of other studies. In 4 cases observed within 24 hours after the onset, the sedimentation time had already begun to decrease. In these cases, the minmum sedimentation time was attained within 5 days. In most cases, the sedimentation time did not begin to return toward the normal until the temperature had been normal for several hours or days. In one patient, the normal time was reëstablished 7 days after the crisis. In 3 others, the suspension stability was decreased for 2 months. Usually, however, the normal was reached 2 or 3 weeks after the crisis. The development of complications caused a renewed phase of rapid sedimentation. In a few cases, the curve of the specific agglutination titer was plotted against changes in sedimentation time, but no relation was evident, supporting previous statements $(4,5)$ that no direct relationship exists between plasma protein changes and specific immune bodies. Of especial interest in this study were the promptness with which disturbance of suspension stability of the plasma occurred after the onset of illness and the length of time required after the crisis before the normal equilibrium was restored.

Blood for determination of the plasma protein fractions was withdrawn at the same time that samples for the observation of sedimentation time were obtained in 6 patients. In 4 of the 6 cases, the total plasma protein was diminished at the height of the febrile period. The fibrinogen was increased during the acute stage of the illness in all except one case, and in that instance the fibrinogen increased during convalescence. In each case the total globulin was increased during the febrile period while the albumin fraction was usually reduced. During convalescence the total protein usually increased, the globulin and fibrinogen decreased and the albumin increased until the normal equilibrium was restored. Exceptions will be pointed out in analyzing the separate cases. The albumin-globulin ratio was 1 or less than 1 during the acute stage and increased during convalescence except in one instance.

A correlation was observed between the viscosity of the plasma and the sedimentation time in the individual cases. As the viscosity increased the sedimentation time decreased. The highest viscosity (2.7) occurred in a case in which the sedimentation time was 8 minutes.

Case I. P. G. Male, aged 21. Type III pneumococcus infection, right lower lobe. An appreciable increase in the total globulin (3.65 grams) and fibrinogen $(0.79 \mathrm{gram})$ was present on the second day of illness. The maximum fibrinogen (1.06 gram) occurred on the sixth day coincident with the minimum sedimentation time of $\mathbf{3 0}$ minutes as shown in Table I. On the fourteenth day, during convalescence, the amount of fibrinogen and globulin had diminished while the sedimentation time had increased. On the thirty-sixth day the blood protein fractions, sedimentation time and viscosity were normal. 
TABLE I

Data on blood

\begin{tabular}{|c|c|c|c|c|c|c|c|c|c|c|c|}
\hline \multirow[b]{2}{*}{ Patient } & \multirow[b]{2}{*}{$\mid \begin{array}{c}\text { Day } \\
\text { after } \\
\text { onset }\end{array}$} & \multicolumn{9}{|c|}{ Plasma } & \multirow{2}{*}{$\begin{array}{l}\text { Blood } \\
\text { sedimen } \\
\text { tation } \\
\text { time }\end{array}$} \\
\hline & & $\begin{array}{c}\text { Total } \\
\text { pro- } \\
\text { tein }\end{array}$ & $\underset{\min }{\text { Albu- }}$ & $\begin{array}{l}\text { Total } \\
\text { glob- } \\
\text { ulin }\end{array}$ & $\begin{array}{c}\text { Fi- } \\
\text { brin- } \\
\text { ogen }\end{array}$ & $\begin{array}{l}\text { Eu- } \\
\text { glob- } \\
\text { ulin }\end{array}$ & $\underset{\substack{\text { Pseudo- } \\
\text { globu- } \\
\text { lin } \\
\text { I }}}{ }$ & $\begin{array}{c}\text { Pseudo- } \\
\text { globu- } \\
\text { lin } \\
\text { II }\end{array}$ & $\frac{\text { Albumin }}{\begin{array}{c}\text { Globulin } \\
\text { ratio }\end{array}}$ & $\begin{array}{c}\text { Vis- } \\
\text { cosity }\end{array}$ & \\
\hline $\begin{array}{c}\text { Case I. } \\
\text { P. G. }\end{array}$ & $\begin{array}{r}2 \\
6 \\
14 \\
36\end{array}$ & $\begin{array}{c}\text { grams } \\
\text { per } \\
100 \\
c c . \\
7.26 \\
6.41 \\
6.04 \\
6.68\end{array}$ & $\begin{array}{c}\text { grams } \\
\text { per } \\
100 \\
c c . \\
3.61 \\
3.49 \\
3.35 \\
4.13\end{array}$ & $\begin{array}{c}\text { grams } \\
\text { per } \\
100 \\
c c . \\
3.65 \\
2.92 \\
2.69 \\
2.55\end{array}$ & $\begin{array}{c}\text { grams } \\
\text { per } \\
100 \\
c c . \\
0.79 \\
1.06 \\
0.79 \\
0.49\end{array}$ & $\begin{array}{c}\text { grams } \\
\text { per } \\
100 \\
c c . \\
0.94 \\
0.20 \\
0.19 \\
0.47\end{array}$ & $\begin{array}{c}\text { grams } \\
\text { per } \\
100 \\
\text { cc. } \\
1.17 \\
1.06 \\
0.98 \\
0.91\end{array}$ & $\begin{array}{c}\text { grams } \\
\text { per } \\
100 \\
c c . \\
0.75 \\
0.59 \\
0.73 \\
0.69\end{array}$ & $\begin{array}{l}0.99 \\
1.19 \\
1.24 \\
1.61\end{array}$ & $\begin{array}{l}1.9 \\
1.5\end{array}$ & $\begin{array}{c}\text { minutes } \\
\\
115 \\
30 \\
97 \\
180+\end{array}$ \\
\hline $\begin{array}{c}\text { Case III. } \\
\text { A. K. }\end{array}$ & $\begin{array}{r}5 \\
30\end{array}$ & $\begin{array}{l}5.61 \\
6.76\end{array}$ & $\begin{array}{l}2.84 \\
3.07\end{array}$ & $\begin{array}{l}2.77 \\
3.69\end{array}$ & $\begin{array}{l}0.27 \\
0.53\end{array}$ & $\begin{array}{l}0.33 \\
0.38\end{array}$ & $\begin{array}{l}0.99 \\
1.95\end{array}$ & $\begin{array}{l}1.20 \\
0.84\end{array}$ & $\begin{array}{l}1.03 \\
0.81\end{array}$ & $\begin{array}{l}2.1 \\
1.6\end{array}$ & $\begin{array}{r}18 \\
155\end{array}$ \\
\hline $\begin{array}{c}\text { Case IV. } \\
\text { F. F. }\end{array}$ & $\begin{array}{l}11 \\
64\end{array}$ & $\begin{array}{l}5.99 \\
6.56\end{array}$ & $\begin{array}{l}2.18 \\
3.73\end{array}$ & $\begin{array}{l}3.81 \\
2.83\end{array}$ & $\begin{array}{l}0.74 \\
0.61\end{array}$ & $\begin{array}{l}0.66 \\
0.52\end{array}$ & $\begin{array}{l}1.31 \\
1.13\end{array}$ & $\begin{array}{l}1.10 \\
0.59\end{array}$ & $\begin{array}{l}0.57 \\
1.31\end{array}$ & $\begin{array}{l}1.8 \\
1.6\end{array}$ & $\begin{array}{c}7 \\
180+\end{array}$ \\
\hline $\begin{array}{c}\text { Case VI. } \\
\text { J. B. }\end{array}$ & $\begin{array}{r}7 \\
48\end{array}$ & $\begin{array}{l}6.55 \\
6.35\end{array}$ & $\begin{array}{l}3.14 \\
3.12\end{array}$ & $\begin{array}{l}3.41 \\
3.23\end{array}$ & $\begin{array}{l}0.59 \\
0.31\end{array}$ & $\begin{array}{l}0.75 \\
0.38\end{array}$ & $\begin{array}{l}1.30 \\
1.98\end{array}$ & $\begin{array}{l}0.77 \\
0.57\end{array}$ & $\begin{array}{l}0.91 \\
0.96\end{array}$ & $\begin{array}{l}2.0 \\
1.5\end{array}$ & $\begin{array}{c}16 \\
180+\end{array}$ \\
\hline $\begin{array}{l}\text { Normal } \\
\text { amounts }\end{array}$ & & 6.67 & 4.07 & 2.59 & 0.29 & 0.68 & 0.94 & 0.68 & 1.57 & 1.7 & $180+$ \\
\hline
\end{tabular}

Case II. M. B. Female, aged 37. Type III pneumococcus infection, right lower lobe. Approximately 18 hours after the initial chill the amount of fibrinogen had increased to 0.93 gram, the maximum observed in this patient. The minimum sedimentation time, however, was not reached until the sixth day when the viscosity was greatest; the fibrinogen diminished but the total globulin increased slightly. During convalescence the amount of fibrinogen and globulin decreased, the viscosity diminished and the sedimentation time increased until normal values were found on the thirty-ninth day. See Figure 1.

Case III. A. K. Male, aged 28. Type III pneumococcus infection, left lower lobe. In this patient the fibrinogen and total globulin were practically normal in amount on the fifth day of illness, yet the sedimentation time was short (18 minutes) and the viscosity 2.1. During convalescence, on the thirtieth day, both the amount of fibrinogen and total globulin was increased, the viscosity decreased and the sedimentation time was nearly normal. See Table I. Observations in this case corroborate the findings of others who showed that increase in sedimentation time did not always parallel decrease in globulins.

Case IV. F. F. Male, aged 37. Pneumococcus group IV infection, right upper and lower lobes. The amount of globulin and of fibrinogen was increased together with an increased viscosity and diminished sedimentation time as shown in Table I. On the sixty-fourth day, the viscosity and sedimentation time were normal but the amount of fibrinogen was still increased to 0.61 gram.

Case V. S. S. Male, aged 29. Group IV pneumococcus infection, four lobes involved. Although the fibrinogen content increased markedly between 
the second and tenth days, the sedimentation time of 20 minutes and viscosity of 1.9 on both occasions remained unchanged. During convalescence, the amount of protein fractions, viscosity and sedimentation time gradually returned to normal. When measured on the ninety-second day the values were approximately normal as shown in Figure 2.



Fig. 1. Chart Representing Case II, M. B. Showing Increase of Fibrinogen on the First Day of Illness

Later the total protein increased together with increase in plasma viscosity and decrease in sedimentation time on the sixth day. The values are normal on the thirty-ninth day.

Case VI. J. B. Male, aged 39. Group IV pneumococcus infection, left lower and right upper lobes. On the seventh day of illness the amount of fibrinogen and of total globulin was moderately increased, the viscosity was 
increased and the sedimentation time diminished (16 minutes). During convalescence on the forty-eighth day, the sedimentation time, viscosity and fibrinogen values were normal but the total globulin fraction was still somewhat higher than normal. (Table I.)

From the results obtained in 3 of these 6 cases there appears to be a fairly close correlation between increase in the amounts of globulin and fibrinogen, increase in viscosity and decrease in the suspension stability

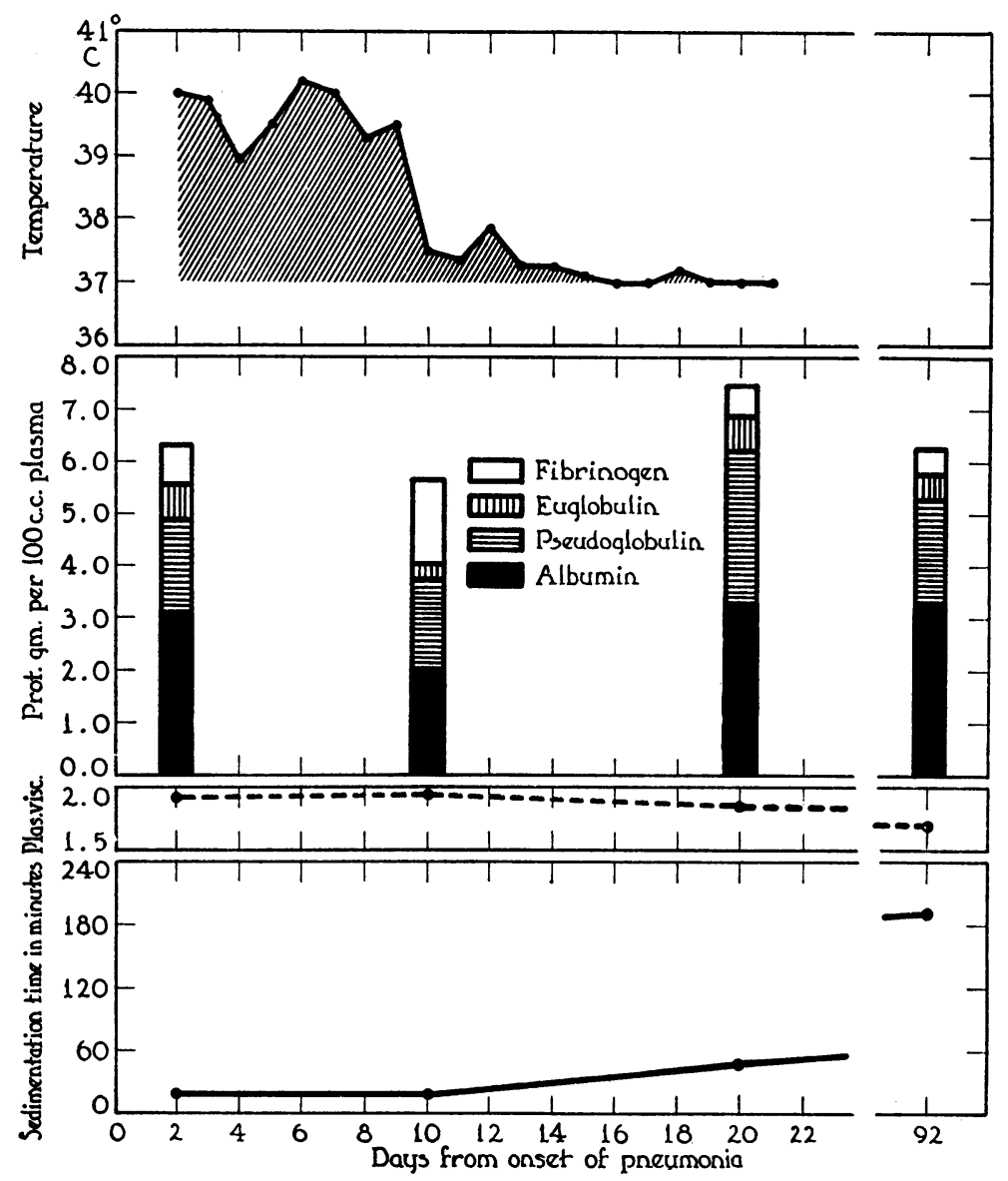

Fig. 2. Chart Representing Case V, S. S. Showing Increased Fibrinugen during the Febrile Period Correlated with Increased Plasma Viscosity and Decreased Sedimentation Time

of the blood in harmony with the views of other observers. On the other hand, in certain cases (II, III and IV) other factors apparently played a role. In Case II the maximum fibrinogen percentage did not coincide with the greatest increase of viscosity and the minimum sedimentation time as illustrated in Figure 1. In Case III, the viscosity and sedimenta- 
tion time were markedly altered yet the fibrinogen percentage was normal and the total globulin only slightly increased. During convalescence, when the viscosity and sedimentation time were normal, the fibrinogen was doubled in amount and the globulin increased by 30 per cent. Changes in cell volume in this case cannot be responsible for the apparent paradoxical behavior since the red cell volume was 34 and 36 per cent on the respective occasions. In Case IV the amount of fibrinogen was still appreciably increased although the viscosity was normal and the sedimentation time had increased from 7 to over 180 minutes. In this patient, the red cell volume increased from 27 per cent during the illness to 35 per cent during convalescence, which partly accounts for increase in the sedimentation time.

The euglobulin fraction in all 6 cases was variable, but was usually reduced during the period of shortest sedimentation time and was still decreased for some time during convalescence. The pseudoglobulins were usually altered with an increase of fraction I and a decrease of fraction? II during the illness.

\section{DISCUSSION}

The results of our study on blood protein changes in lobar pneumonia were for the most part in harmony with those of many other similar studies. The total plasma protein content varied considerably, but in general tended to be diminished during the febrile period. In 2 cases it was slightly increased over the usual normal standard. During the febrile period, the protein may be relatively diminished due to water retention or actually diminished because of decreased intake of food and increased metabolism $(23,24)$. The amount of fibrinogen was usually increased, in one case to as much as $\mathbf{5}$ times its normal amount. The greatest amount was usually present during the illness, but in 1 case during convalescence. The total globulin fraction was increased in all 6 cases during the disease and in 2 cases reached its maximum during convalescence, similar to the observations of Loeper et al. (25). In 3 cases, the amounts of fibrinogen and globulin were increased very early in the disease, several days before the anticipated presence of demonstrable immune bodies, corroborating the opinion of others that no correlation exists between changes in the concentration of proteins in the blood and specific agglutinins. Especially interesting was the prompt increase in the amount of fibrinogen within a few hours after the onset and the long period of time occasionally required after the crisis before it returned to the normal level.

The albumin-globulin ratio during the acute stage of the disease varied from 0.57 to 1.19. During convalescence, the ratio increased in most cases. In 2 cases, the ratio was less than 1 during convalescence, and in 4 cases it varied from 1.17 to 1.62 .

It appeared that increase in fibrinogen and globulin usually, but not 
always, paralleled a decrease in the sedimentation time of erythrocytes, as shown previously by others $(18,19,20,21)$. In cases manifesting an exception to the rule, no explanation is available to account for the lack of correlation. Changes in cell volume, color index or anemia could not be held accountable. It is possible that unknown qualitative changes in the protein fractions may play a role. The changes in the sedimentation time were in all cases parallel with changes in the viscosity of the plasma. The sedimentation time always shortened with increase in plasma viscosity.

The prompt increase of fibrinogen observed soon after the onset of lobar pneumonia resembles the prompt increase of this protein fraction observed by Löhr (26) and others to occur 1 to 4 hours after non-specific protein injection. The simultaneous increase of fibrinogen, increase of leukocytes and decrease of platelets in lobar pneumonia point to a common site of disturbance, probably in the hematopoietic organs. But, although after the crisis the number of leukocytes diminish and the platelets increase, the amount of fibrinogen in a number of instances continued to increase or remained at an abnormally high level, and in certain cases a month or more elapsed before the amount was reduced to normal. The prolonged period of hyperinosis is not in harmony with the view $(4,5)$ that globulins in the blood increase merely as a result of transient metabolic disturbances which occur during the illness. There may, however, be some relationship between the prolonged increase observed in most cases and the gradual resolution of the exudate in the consolidated lung composed largely of leukocytes and fibrin. It is known that the process of resolution may continue for varying periods after the crisis. Furthermore, fibrinogen-like and globulin-like proteins have been derived from leukocytes in vitro (26). Observations on the correlation of blood protein changes with the progress of resolution were not made in this investigation, but studies are in progress at present.

\section{SUMMARY}

The total plasma protein is usually decreased during the febrile period of lobar pneumonia. The fibrinogen and globulin fractions are increased. The increase occurs promptly after the onset and a high level persists for varying periods, up to 2 months after the crisis.

The viscosity of the plasma increases and the sedimentation time of erythrocytes decreases, usually, but not always, in close correlation with increase of fibrinogen and globulin.

\section{BIBLIOGRAPHY}

1. Reimann, H. A., Ann. Int. Med., 1932, vi, 362. The Significance of Fever and Blood Protein Changes in Regard to Defense against Infection.

2. Tillet, W. S., and Abernethy, T. J., Bull. Johns Hopkins Hosp., 1932, 1, 270. Serological Reactions with Hemolytic Streptococci in Acute Bacterial Infections. 
3. Langstein, L., and Mayer, M., Beitr. z. chem. Phys. u. Path., 1904, v, 69. Über das Verhalten der Eiweisskörper des Blutplasmas bei experimentellen Infektionen.

4. Glaessner, K., Ztschr. f. exper. Path. u. Pharm., 1905, ii, 154. Über das Verhalten des Blutglobulins beim Immunisirungsvorgange.

5. Hurwitz, S. H., and Meyer, K. F., J. Exper. Med., 1916, xxiv, 515. Studies on the Blood Proteins. I. The Serum Globulins in Bacterial Infection and Immunity.

Meyer, K. F., Hurwitz, S. H., and Taussig, L., J. Infect. Dis., 1918, xxii, 1. III. Albumin-Globulin Ratio in Antitoxic Immunity.

6. Schmidt, A. A., and Tuljtschinskaja, K., Ztschr. f. Immunität. u. exper. Therapie, 1931, 1xx, 8. Biochemische Beiträge zur Immunitätsforschung. I. Der Einfluss der Immunisation auf den Serumeiweisskörpergehalt.

7. Lloyd, R. B., and Paul, S. N., Ind. J. Med. Res., 1929, xvii, 583. Serum Protein Changes in Malaria and Typhoid Fever with Suggestions as to their Possible Bearing on Immunity.

8. Kumpf, A. E., Arch. Path., 1931, xi, 335. The Blood Proteins with Special Reference to the Changes Occurring in Renal Diseases.

9. Fahraeus, R., Acta med. Scandinav., 1921, 1v, 1. The Suspension Stability of the Blood. (Part I. Historical Review.) Physiol. Rev., 1929, ix, 241. The Suspension Stability of the Blood.

10. Starlinger, W., Biochem. Ztschr., 1921, cxiv, 129. Über Agglutination und Senkungsgeschwindigkeit der Erythrocyten.

11. Gram, H. C., Arch. Int. Med., 1921, xxviii, 312. On the Causes of the Variations in the Sedimentation of the Corpuscles and the Formation of the Crusta Phlogistica ("Size," "Buffy Coat") on the Blood.

12. Westergren, A., Theorell, H., and Widström, G., Ztschr. f. d. ges. exper. Med., 1931, lxxv, 668. Plasmaeiweiss, Blutlipoide, Erythrocyten und Senkungsreaktion.

13. Motzfeldt, K., Acta med. Scandinav., 1932, Supp. 1, 315. The Sedimentation Reaction in Pneumonia.

14. Rourke, M. D., and Ernstene, A. C., J. Clin. Invest., 1930, viii, 545. A Method for Correcting the Erythrocyte Sedimentation Rate for Variations in the Cell Volume Percentage of Blood.

15. Plass, E. D., and Rourke, M. D., J. Lab. and Clin. Med., 1927, xii, 735. The Effect of Venous Stasis on the Proteins of Blood Plasma and on the Rate of Sedimentation of the Red Blood Corpuscles.

16. Bendien, W. M., and Snapper, I., Biochem. Ztschr., 1931, ccxxxv, 14. Zusammenhang zwischen der Senkungsgeschwindigkeit der roten Blutkörperchen und dem Eiweissspektrum.

17. Ohno, M., Ztschr. f. d. ges. exper. Med., 1926, lii, 643. Die Senkungsgeschwindigkeit der menschlichen Erythrocyten in Beziehung zum Färbeindex.

18. Salomon, A., Ztschr. f. klin. Med., 1924, xcix, 329. Über die Senkungsreaktion der roten Blutkörperchen und ihre Beziehung zu den Globulinen des Blutes.

19. Nitschke, A., Ztschr. f. d. ges. exper. Med., 1929, lxiv, 120 . Über den Einfluss der Plasmaeiweissstruktur auf die Senkungsgeschwindigkeit der roten Blutkörperchen.

20. Jones, L. R., J. Lab. and Clin. Med., 1929, xv, 209. Plasma Protein in Relation to Suspension Stability of Erythrocytes and Precipitation of Serum Protein with Aluminum Sulphate. Am. Rev. Tuberc., 1931, 
xxiii, 325. Plasma Protein, Red Cell Sedimentation and Serum Lability of the Blood in Tuberculosis.

21. Oelkers, H. A., and Ohnesorge, G., Ztschr. f. d. ges. exper. Med., 1931, Ixxviii, 156. Eiweissgehalt und kolloidosmotischer Druck im Serum von Fieberkranken.

22. Berglund, H., Scriver, W., and Medes, G., In Press. Plasma and Urinary Proteins. Lea and Febiger, Philadelphia, $\mathrm{Pa}$.

23. Soule, H. C., Buckman, T. E., and Darrow, D. C., J. Clin. Invest., 1928, v, 229. Blood Volume in Fever.

24. Buccianti, E., Il Policlinico, Sez. Med., 1931, xxxviii, 138. Il Comportamento del Volume Totale di Plasma Circolante nelle Malattie Infettive Acute.

25. Loeper, M., Ravier, J. de Sèze, and Lebert, Compt. rend. Soc. de biol., 1929, ci, 423. La Globulinémie à la Période Critique de la Pneumonie.

26. Löhr, H., Ztschr. f. d. ges. exper. Med., 1922, xxvii, 1. Die Beeinflussung der Blutkörperchensenkungsgeschwindigkeit durch Reizstoffe.

27. Reimann, H. A., Medes, G., and Fisher, L. C. To be published. 